\title{
ADRENAL METASTASES OF RENAL CELL CARCINOMA WITH INTRAVENOUS TUMOR THROMBI OF THE INFERIOR VENA CAVA (two case reports with literature review) ${ }^{*}$
}

\author{
D. V. Shchukin ${ }^{1,2}$, V. N. Lesovoy ${ }^{1,2}$, U. M. Balarabe', G. G. Khareba ${ }^{1,2}$, \\ I. M. Antonian ${ }^{3}$, M. P. Kopytsya ${ }^{4}$, A. I. Harahatyi ${ }^{1,2}$, A. V. Shus ${ }^{3}$ \\ ${ }^{1}$ Kharkiv National Medical University, Kharkiv, Ukraine; \\ ${ }^{2}$ MHI «V. I. Shapoval Regional Medical Clinical Center of Urology and Nephrology», Kharkiv, Ukraine; \\ ${ }^{3}$ Kharkiv medical academy of postgraduate education, Kharkiv, Ukraine; \\ ${ }^{4}$ L. T. Malaya National Institute of Therapy of NAMS of Ukraine, Kharkiv, Ukraine \\ urology.edu.ua@gmail.com
}

In clinical studies the incidence of ipsilateral adrenal metastases in patients with renal cell carcinoma (RCC) ranges from $1.1 \%$ to $10 \%$, and the rate of contralateral metastases usually does not exceed $1 \%$ [1-4]. Information about bilateral RCC metastases is limited to about two dozens of reports [5-9].

Intravenous extension is one of the attributes characterizing the neoplastic process. Microscopically this phenomenon is characteristic for many tumors, however massive macroscopic growth into the vena cava can be detected only with certain types of tumors though, specifically, renal cell carcinoma and various types of adrenal tumors [10-13]. So far in the worldwide literature only a few reports describe intravenous extension of distant RCC metastases, in particular, adrenal metastases [14-18].

Case study \#1. A 60 -year-old patient was hospitalized in October 2016 with complaints of right lower back pain and general weakness. Ultrasound and MDCT revealed a lesion in the lower pole of the right kidney of $60 \times 68 \mathrm{~mm}$. Right renal vein had no signs of tumor thrombosis. Retroperitoneal lymph nodes were not enlarged. In both lungs multiple soft tissue masses ranging from 5 to $12 \mathrm{~mm}$ were detected. In both right and left adrenal glands masses of $48 \mathrm{~mm}$ and $56 \mathrm{~mm}$, respectively, were found. Assessment of the inferior vena cava

* The research was carried out as part of investigation work at the Kharkiv National Medical University, «Improvement and development of diagnostic and surgical treatment methods involving minimally invasive techniques for disorders and injuries of abdominal and chest organs, upper and lower extremity vessels in patients at high risk of postsurgical complications».

Institution, which financed the research: Ministry of Health of Ukraine.

The authors assume responsibility for the published work.

The authors guarantee absence of competing interests and their own financial interest when carrying out the research and writing the article.

The manuscript was received by the editorial staff 28.11.2019. 


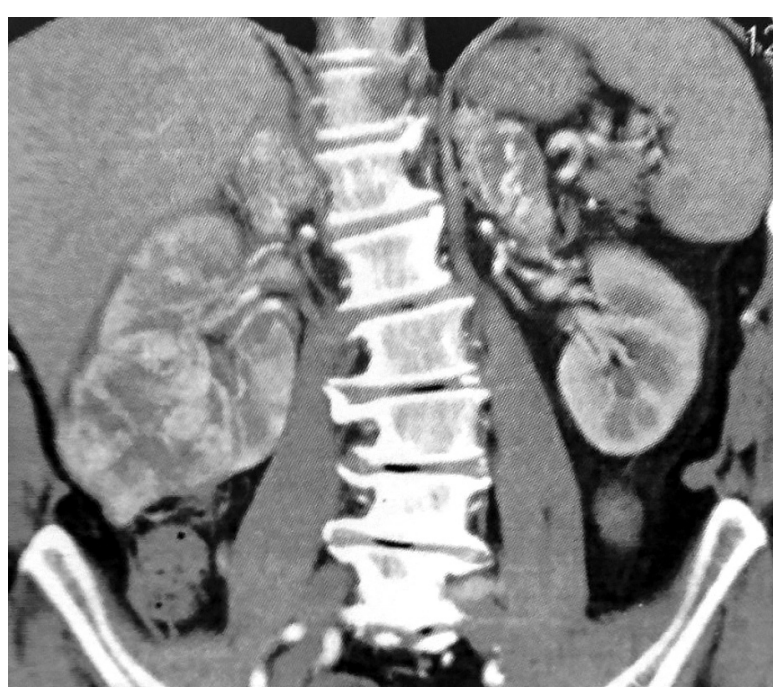

a) MDCT. Coronal reconstruction represents the right kidney tumor and tumors of both adrenal glands

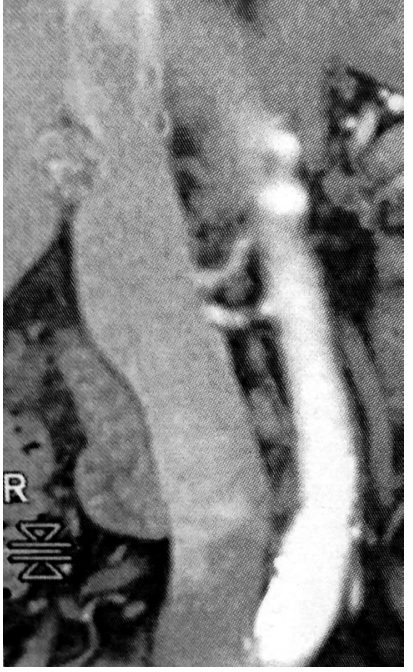

b) Coronal reconstruction demonstrates the right adrenal gland tumor extension to the subhepatic segment of the IVC

Figure 1

demonstrated the spread of the right adrenal mass into its lumen within $1.5 \mathrm{~cm}$.

The patient's general condition was satisfactory (ECOG performance status 0). Blood pressure monitoring revealed moderate arterial hypertension (130/90 $\mathrm{mm} \mathrm{Hg})$. The level of cortisol, metanephrine, normetanephrine, blood aldosterone, 17- $\mathrm{OH}$ corticosteroids and 17 oxyketosteroids of 24-hour urine had normal values. In this regard, the adrenal neoplasms were recognized as hormonally inactive. $\mathrm{Hb}=$ $122 \mathrm{~g} / \mathrm{l}$, erythrocytes $=3,8 \times 10^{12}$, leukocytes $=$ $8,0 \times 10^{9} \mathrm{~g} / \mathrm{l}$. Blood urea nitrogen $=6.8 \mathrm{mmol} / \mathrm{l}$, creatinine $=98 \mu \mathrm{mol} / \mathrm{l}$, glucose $=5.6 \mathrm{mmol} / \mathrm{l}$. Taking into account the data obtained from the assessment, the diagnosis was the right kidney tumor T3aN0M1 with synchronous metastases into both adrenals and the right adrenal gland tumor extension into the inferior vena cava. After discussion with the patient the treatment plan was agreed: cytoreductive nephrectomy with resection of the left adrenal gland and right adrenalectomy or bilateral adrenalectomy.

The patient underwent Chevron incision laparotomy. The duodenum was mobilized using Kocher maneuver. Isolation of the inferior vena cava and both renal veins revealed the right adrenal gland tumor penetrating the subhepatic segment of the IVC with the left adrenal gland tumor expanding through the suprarenal vein up to its fusion with the left renal vein. The right renal artery was ligated and transsected in the interaortocaval segment. After dissection and ligation of the right renal vein and the ureter, the kidney was removed.

Both adrenals were isolated from the surrounding tissue. In addition, it was discovered that the adrenal tissue was completely replaced by the tumors. Due to infeasibility of resection of neither one of the adrenal glands it was decided to perform bilateral adrenalectomy. Vascular clamps were placed on the IVC and on the left adrenal vein distal to the tumor masses. Lateral resection of IVC was performed in the area of the right adrenal vein mouth. The left adrenal vein was dissected away from the left renal vein. Both adrenals were removed along with the tumor intravenous thrombi. The vein defects were closed with Prolene suture 5-0.

The postoperative period was uneventful. Hormone replacement therapy with glucocorticoids and mineralocorticoids was used at the same time. The patient was discharged on the 9 th day after surgery. Hormone replacement therapy is ongoing under the care of an endocrinologist. 1 month after the surgery the first line of targeted therapy was initiated (pazopanib $800 \mathrm{mg}$ once daily). The 2 - and 6 -month MDCT demonstrated no signs of tumor progression. Most lung tumor lesions decreased in size or remained without change. The patient had no complaints. Blood pressure was 


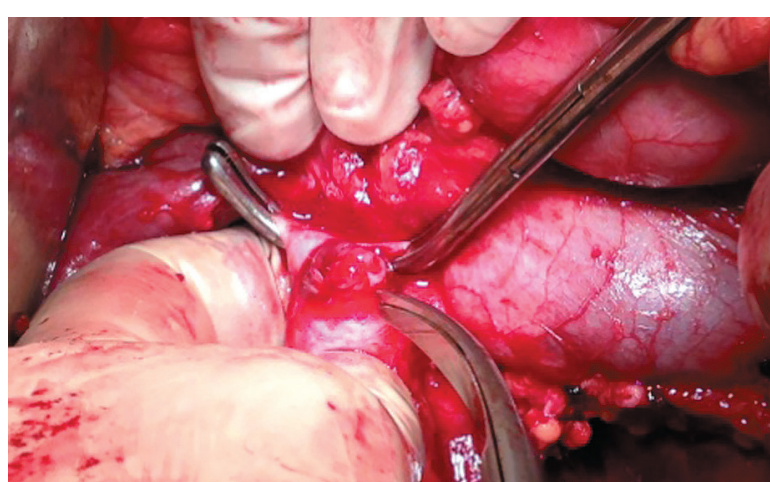

a) Tumor thrombus removed from the lumen of the IVC

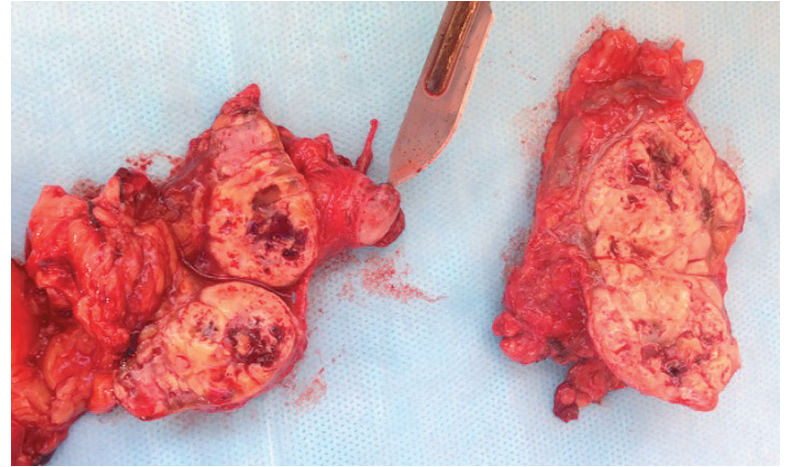

b) Gross specimens of both adrenal glands with intravenous tumor thrombi

Figure 2

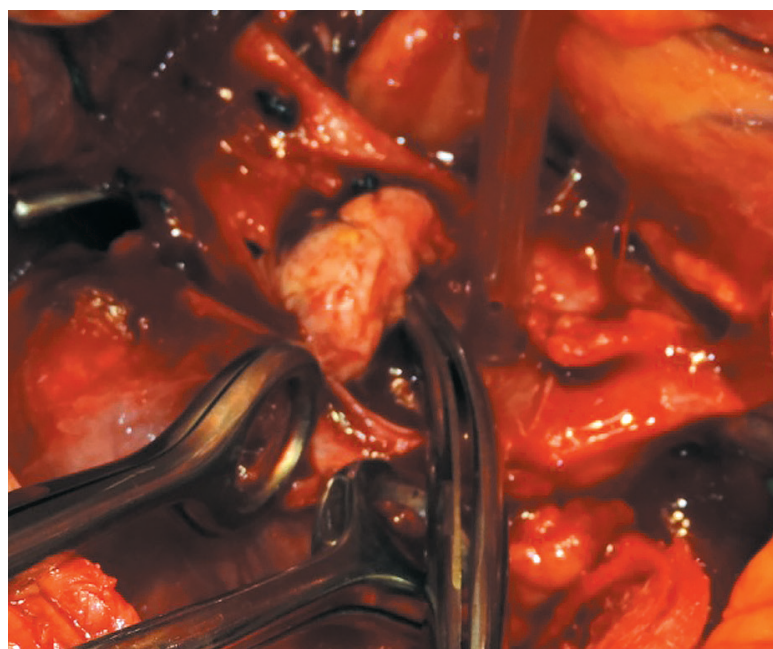

a) Tumor thrombus in the lumen of the IVC

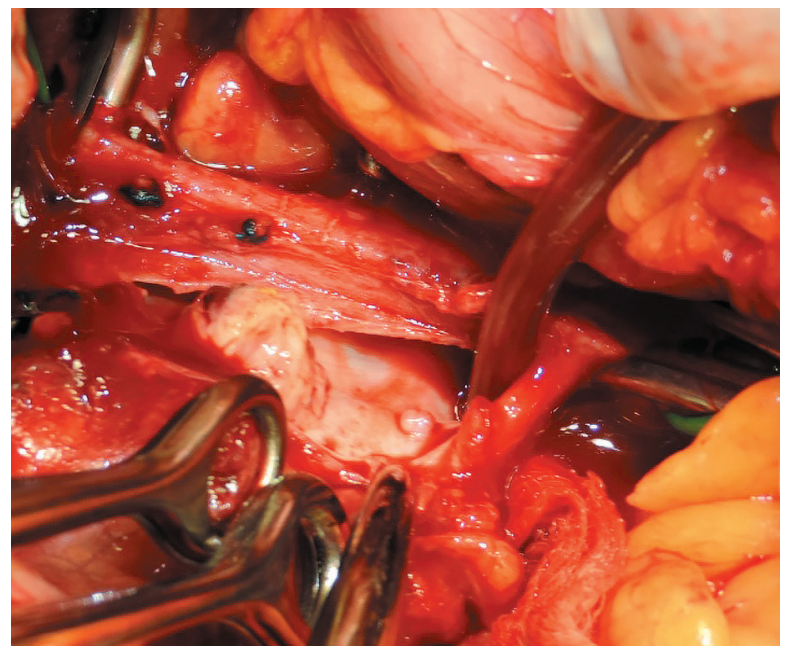

b) The metastasis into the wall of the IVC, located next to the tumor thrombus

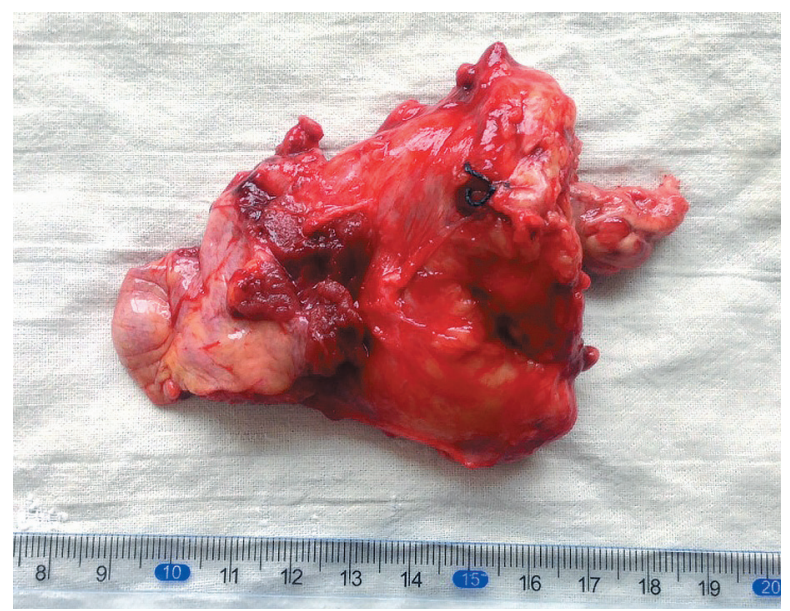

c) Gross specimen of the right adrenal gland with tumor thrombus

Figure 3

110/70 mmHg. Addison disease symptoms were absent.

Case study \#2. A 53-year-old patient was admitted to hospital in February 2013, with complaints of hematuria and weight loss (4 kg within 6 months). MDCT examination revealed the right kidney middle segment tumor of $10 \times 12 \mathrm{~cm}$ without signs of local invasion, extension to the regional lymph nodes and distant 
metastases. Considering these findings, radical nephrectomy with paracaval lymphadenectomy was performed. Right adrenalectomy was not performed, since computed tomography had revealed no signs of the right adrenal gland lesions. The final histopathological examination revealed poorly differentiated (Fuhrman Grade 3) clear cell renal cell carcinoma with signs of perinephric fat invasion (T3aN0M0). The postoperative period was uneventful. The patient was discharged from hospital 9 days later in satisfactory condition. However, after 6 months the follow-up MDCT revealed a tumor of the right adrenal gland of $2.5 \times 3.0 \mathrm{~cm}$ with extension to the lumen of the inferior vena cava via the adrenal vein. The intravenous part of the tumor measured $2.2 \times 1.2 \mathrm{~cm}$. No distant metastases to the lungs or other organs were found.

The patient's ECOG performance status was 0 . Blood pressure monitoring revealed arterial hypertension (140/90 mm Hg). The level of cortisol, metanephrine, normetanephrine, blood aldosterone, 17-OH corticosteroids and 17 oxy-ketosteroids of 24-hour urine had normal values. $\mathrm{Hb}=116 \mathrm{~g} / \mathrm{l}$, erythrocytes $=3.6 \times 10^{12}$, leukocytes $=7.0 \times 10^{9} \mathrm{~g} / \mathrm{l}$. Blood urea nitrogen $=$ $8.8 \mathrm{mmol} / \mathrm{l}$, creatinine $=112 \mu \mathrm{mol} / 1$, glucose $=$ $4.6 \mathrm{mmol} / \mathrm{l}$. Following the assessment, the diagnosis was established: metachronous renal cell carcinoma metastasis into the ipsilateral adrenal gland with intravenous extension to the subhepatic segment of the inferior vena cava In October 2013 the patient underwent right adrenalectomy with thrombectomy and lateral resection of the inferior vena cava with the use of thoracolaparotomic approach to the 10th intercostal space. For vascular isolation of the tumor thrombus vascular clamps were placed on the IVC above and below the thrombus. After opening the vena cava it was found that intraluminal tumor masses were attached to its wall in the site of the confluence of the right adrenal vein. Furthermore, $10 \mathrm{~mm}$ below the tumor thrombus on the surface of the caval endothelium another tumor was found - metastasis to the IVC wall measuring about $5 \mathrm{~mm}$. In this regard, lateral resection of the IVC was performed within $3.0 \mathrm{~cm}$. The resection margins were located within $5 \mathrm{~mm}$ of intraluminal tumor lesions.

The postoperative period was uneventful. Patient was discharged from hospital on the 10th day after surgery. After 6 months multiple lung metastases were found. The therapy with pazopanib (800 mg once daily) was initiated. 3 months later tumor progression (lung metastase increase in number and size) was identified. The patient died in 5 months (the total of 14 months after surgery) from tumor intoxication.

\section{DISCUSSION}

Intravenous extension of renal cell carcinoma adrenal metastases can be viewed in several ways. It is possible, that this phenomenon represents a specific feature of this neoplasm. Though, this assumption must be supported by similar incidence of RCC metastases invasion into the lumen of the major venous vessels. On the other hand, primary adrenal gland tumors by themselves have a distinct tendency to intravenous extension. Specifically, the adrenal pheochromocytomas are accompanied by this phenomenon in $2 \%$ of cases, and adrenocortical carcinomas in 9\%-30\% [19-21]. A large retrospective study in an Australian hospital presented 30 years' experience of treatment of 464 patients with metastases into the adrenal glands. The authors have demonstrated that the rate of detection of adrenal metastases on autopsy is $3.1 \%$, while at adrenalectomy is $7.5 \%$ [22].
In another work, which included 52 patient with various tumor metastases into the adrenal glands, localization of primary tumors was distributed as follows: the kidneys (28.8\%), the lungs $(21.2 \%)$, the intestine (13.4\%), unknown localization $(9.6 \%)$, the stomach $(5.8 \%)$, melanoma (5.8\%), others (15.4\%) [23]. High proportion of adrenal metastases, originating from $\mathrm{RCC}$, is also confirmed by clinical trials data, which studied the rate of occurrence of adrenal metastases of this tumor type. The studies have demonstrated that adrenal metastases are detected in 1\%-10\% of patients with renal cell carcinoma [1-4].

A distinct tendency of RCC towards macroscopic intravenous extension is widely known and well documented by many authors (20\%-26\%) [24, 25]. Though, can we declare the affinity to the venous route of 
tumor extension for this type of cancer metastases? From our point of view, this is not a general tendency, since there are only a few reports on this phenomenon in the literature. In particular, a group of British authors presented a case study of metastatic renal cancer extending from the thoracic spine via v. azygos into the superior vena cava. In addition, there were significant clinical signs of the superior vena cava obstruction [26].

Previously we described a patient with multiple RCC metastases into the liver, one of which penetrated into the lumen of a portal vein branche [27]. This feature was discovered by ultrasonography and was histologically verified during autopsy. It is noteworthy, that the patient had been operated on 4 months before for renal cancer with tumor thrombus at the level of the subhepatic IVC segment. Along with liver metastasis, invading the portal vein, the patient also had a recurrent neoplastic thrombus, reaching retrohepatic segment of the inferior vena cava. A very interesting case was presented by Yachida S, et al., who discovered invasion of pancreatic RCC metastasis into Wirsung's duct in the form of tumor «thrombus» in three patients [28]. There are two more similar cases in the literature. At the same time it is believed that extension into the main pancreatic duct is a distinguishing feature of renal cancer metastases to the pancreas, since it is not typical for primary pancreatic tumors. There is an undoubtful similarity between intravenous and intraductal invasion, although the small number of observations does not allow us to claim its accuracy.
No less unique are the reports on extension of hepatic renal cell carcinoma metastases into either the hepatic duct lumen or the common bile duct lumen [29]. In addition, the tumor inside the duct also resembles a thrombus. In the world literature only three cases of this phenomenon are described. However, the invasion into the lumen of the biliary tract is not unique to renal cancer metastases, since similar cases of colon cancer and malignant melanoma metastases are described [30].

How common is intravenous extension of adrenal metastases? In the world literature we found only 7 cases, including two clinical cases of our own. Table 1 presents a summary on the subject.

Among all 7 patients ipsilateral metastases were found in 2 cases, contralateral in 3 cases, and bilateral in 2 . Synchronous adrenal metastases were revealed only in 3 patients, in the rest of cases the metastases occurred at various intervals after surgery. One of our patients had extremely rare synchronous RCC metastases into both adrenal glands with synchronous extension into the venous system. Interesting, that renal tumor had no signs of intravenous invasion. Previously no such reports were presented in the literature.

How often do other cancer adrenal metastases propagate into the venous system? The literature analysis demonstrated 27 cases of this phenomenon with various types of tumors (Table 2). More than half of these clinical cases $(55.6 \%, 15$ patients) referred to he-

Table 1

Case reports of intravenous extension of adrenal RCC metastases

\begin{tabular}{c|c|c|c}
\hline № & Authors & Lesion side & Synchronicity \\
\hline 1 & Pereverzev AS, $1990[16]$ & $\begin{array}{c}\text { bilateral metastases with one } \\
\text { thrombus }\end{array}$ & synchronous \\
\hline 2 & Von Knobloch R, 2000 [14] & contralateral & synchronous \\
\hline 3 & Rosenblatt GS, 2009 [17] & ipsilateral & metachronous \\
\hline 4 & Ploumidis A, 2015 [18] & contralateral & metachronous \\
\hline 5 & Piotrowicz, 2015 [15] & contralateral & synchronous \\
\hline 6 & Authors' case report\# 1 & $\begin{array}{c}\text { bilateral metastases } \\
\text { and bilateral thrombi }\end{array}$ & metachronous \\
\hline 7 & Authors' case report\# 2 & ipsilateral
\end{tabular}


Case reports of intravenous extension of adrenal metastases

Table 2 of various cancer types

\begin{tabular}{c|c|c|c}
\hline № & Authors & $\begin{array}{c}\text { Number } \\
\text { of patients }\end{array}$ & \\
\hline 1 & Takada K, 1989 [31] & 1 & Hepatocellular carcinoma \\
\hline 2 & Sakamoto Y, 1999 [32] & 3 & Hepatocellular carcinoma \\
\hline 3 & Morimoto T, 1999 [33] & 1 & Hepatocellular carcinoma \\
\hline 4 & Shimahara Y, 1999 [34] & 1 & Hepatocellular carcinoma \\
\hline 5 & Momoi H, 2002 [35] & 7 & Hepatocellular carcinoma \\
\hline & Lucon MA, 2004 2004$)[13]$ & 6 & $\begin{array}{c}\text { Pelvic cancer } \\
\text { Wilms' Tumor } \\
\text { Lung cancer }\end{array}$ \\
\hline 6 & (literature data before & Thyroid cancer \\
\hline 7 & Paparel P, 2004 [36] & 1 & Thyroid cancer \\
\hline 8 & Ben Abid S, 2005 [37] & 1 & Hepatocellular carcinoma \\
\hline 9 & Fernández Sarabia MT, 2008 [38] & 1 & Breast cancer \\
\hline 10 & Wakayama K, 2013 [39] & 1 & Hepatocellular carcinoma \\
\hline 11 & Tokue H, 2014 [40] & 1 & Ovarian cancer \\
\hline 12 & Yang ST, 2014 [41] & 1 & Uterine leiomyosarcoma \\
\hline 13 & Filippi L, 2014, [42] & 1 & Lung cancer \\
\hline 14 & Vishnevskǐ AV, 2015 [43] & 1 & Colorectal cancer \\
\hline
\end{tabular}

patocellular carcinoma, which were described mostly by Japanese authors.

The data presented indicates that extension of adrenal RCC metastases into the lumen of the large venous vessels is not rare and is the second most common cancer after hepatocellular carcinoma. However, due to the small total number of observations we cannot consider this phenomenon as manifestation of affinity of this cancer type to intravenous extension.

Synchronous bilateral RCC metastases occur quite rarely. Thus, von Knobloch R. et al. found adrenal metastases during surgical treatment of 617 patients with RCC in 23 $(3.7 \%)$ cases. At the same time, bilateral metastases were found in $6(1 \%)$ cases [44]. In the study by Antonelli A. et al. analyzing the results of treatment of 1179 patients the incidence of bilateral adrenal lesions did not exceed $0.2 \%$ [2]. Nevertheless, the literature does not present a lot of studies on the rate of occurrence and clinical features of bilateral adrenal RCC metastases. Basically, these are reports on a few clinical cases [5-9].

Surgical management of renal cell carcinoma with metastases into both adrenal glands is a complex task, since in most cases it requires bilateral adrenalectomy and subsequent hormone replacement therapy with glucocorticoids and mineralocorticoids. In one of our patients with bilateral adrenal metastases this problem was considerably more difficult, since the rightsided tumor synchronously extended into the inferior vena cava, and the left-sided one invaded the left adrenal vein. We decided on bilateral adrenalectomy with one stage thrombectomies, since the general condition of the patient was stable and nephrectomy passed without complications. It should be noted that resection of tumor thrombi with adrenal tumors has some peculiarities.

First of all, with the right-sided metastases the tumor easily extends via the adrenal vein to the retrohepatic segment and «higher» segments of the inferior vena cava. In most cases either mobilization of the liver with control of supradiaphragmatic part of the inferior vena cava, or the use of cardiopulmonary bypass is required. Secondly, with the left-sided metastases the tumor thrombus can invade not only the left adrenal vein, but the left renal vein also. Therefore, in order to preserve the left kidney, 
resection and difficult vascular reconstruction of the renal vein may be necessary.

It is believed that in order to maintain adequate adrenal function $10 \%$ of adrenal tissue is required [7, 45]. Therefore, in recent years for adrenal tumors the organ sparing surgeries have been actively performed [46]. It should be noted, that these surgeries may not be always feasible though.

One should consider the size of the lesion, its localization, the volume of remnant adrenal tissue, as well as the degree of integrity of the adrenal vessels after resection. In our clinical case it was impossible to perform neither right-sided, nor left-sided organ sparing surgery, since the tumors had replaced the larger portion of the adrenal glands and extended into the main adrenal veins.
Although modern replacement therapy with glucocorticoids and mineralocorticoids is effective and safe, the patients with Addison disease due to bilateral adrenalectomy can have signs of acute adrenal insufficiency in various stress situations. Besides, in most cases, these patients suffer from side effects of steroid therapy, such as gastritis, hypertension and hypokalemia [5, 46].

Another important issue is feasibility of targeted therapy in presence of iatrogenic Addison disease. In our patient treatment with pazopanib was prescribed due to presence of pulmonary metastases after nephrectomy with bilateral adrenalectomy. At the same time, we found no significant side effects, and hormone replacement therapy did not require any adjustment.

\section{CONCLUSION}

We have presented two case reports on intravenous extension of renal cell carcinoma adrenal metastases. One of them for the first time in worldwide literature presents intravenous extension of synchronous bilateral adrenal metastases from RCC. Although these cases are extremely rare, it is necessary to take into account possibility of presence of venous tumor thrombi with adrenal metastases. The incidence of this phenomenon of RCC is in the second place after hepatocellular carcinoma. Organ-sparing surgical technique in these patients is not feasible. Targeted therapy along with hormone replacement therapy was not accompanied by increased side effects or exacerbation of adrenal insufficiency after removal of both adrenal glands.

\section{REFERENCES}

1. Siemer S, Lehmann J, Kamradt J, et al. J Urol 2004; 171: 2155-2159. doi: 10.1097/01.ju.0000125340.84492.a7.

2. Antonelli A, Cozzoli A, Simeone C, et al. BJU Int 2006; 97(3): 505-508.

3. Lau WK, Zincke H, Lohse CM, et al. BJU Int 2003; 91: 775-779. doi: 10.1046/j.1464-410X.2003.04237.x.

4. Weight CJ, Kim SP, Lohse CM, et al. Eur Urol 2011; 60(3): 458-464.

5. Koutalellis GE, Felekouras E, Evangelou C, et al. Cases $J$ 2009; 2: 7298. doi: 10.4076/1757-1626-2-7298.

6. Yu CC, Huang JK, Tzeng WS, et al. Eur Urol 1992; 22: 335-338

7. Selli C, Carini M, Barbanti G, et al. J Urol 1987; 137: 480-482.

8. Schomer NS, Mohler JL. J Urol 1995; 153: 1196-1198. doi: 10.1016/S0022-5347(01)67550-5.

9. Öztürk H. Oncology 2015; 9: 1897-1901. doi: 10.3892/ ol.2015.2915.

10. Tanaka A, Takeda R, Mukaihara S, et al. J Gastroenterol 2002; 37: 220-228. doi: 10.1007/s005350200025.
11. Takahashi K, Furuse M, Hanaoka H, et al. J Comput Tomogr 2000; 24: 557- 561.

12. Hoehn W, Hermanek P. Eur Urol 1983; 9.

13. Lucon AM, Machado MCC, Pereira MAA. BJU Int 2004; 94(1): 70-73. doi: 10.1111/j.1464-410X.2004.04903.x

14. von Knobloch R, Hegele A, Kälble T, Hofmann R. Scand J Urol Nephrol 2000; 34(2): 109-113. doi: 10.1080/00365 5900750016715.

15. Piotrowicz S, Muśko N, Kozikowski M, et al. J Ultrason 2015; 15(63): 438-442. doi: 10.15557/JoU.2015.0041.

16. Pereverzev AS, Andreev AA. Vestn Khir Im I I Grek 1990; 144(6): 53-55.

17. Rosenblatt GS, Takesita K, Fuchs GJ, et al. Urology 2009; 74(2): 290-291. doi: 10.1016/j.urology.2009.02.055.

18. Ploumidis A, Spinoit AF,2, De Naeyer G, et al. Int J Med Robot 2015; 11(4): 413-417. doi: 10.1002/rcs.1641.

19. Musholt ThJ. European Surg 2003; 35(2): 97-101. https://doi.org/10.1046/j.1682-4016.2003.03043.

20. Hedican SP, Marshall FF. J Urol 1997; 158: 2056-2061. 
21. Lucon AM, Pereira MAA, Mendonca BB, et al. J Urol 1997; 157: 1208-1212.

22. Lam KY, Lo CY. Clin Endocrinol (Oxf) 2002; 56(1): 95101. doi: 10.1046/j.0300-0664.2001.01435.x.

23. Lo CY, van Heerden JA, Soreide JA, et al. Br J Surg 1996; 83(4): 528-531. doi: 10.1002/bjs.1800830432.

24. Bensalah K, Guille F, De la Taille A, et al. Eur Urol $2005 ; 4: 52$.

25. Blute ML, Leibovich BC, Lohse ChM, et al. BJU Int 2004; 94: 33-41. doi: 10.1111/j.1464-410X.2004.04897.x.

26. Strugnell M, Gibson M, Hopkins R. BJR 2005; 78: 6567. doi: $10.1259 / \mathrm{bjr} / 68967544$.

27. Shhukin DV, Iljuhin JuA. Hirurgija opuholevyh trom bov nizhnej poloj veny pri rake pochki, Belgorod, 2007: $196 \mathrm{p}$.

28. Yachida S, Fukushima N, Kanai Y, et al. Jap J Clin Oncol 2002; 32: 315-317. doi: 10.1093/jjco/hyf066.

29. Ueda K, Ohory M, Taka J, Kusano M. Surg Todey 2002; 32: 458-461. doi: 10.1007/s005950200076.

30. Roslin JJ, Kuchenbecker S, Longmire WP, Tompkins RK. Arch Surg 1984; 119: 1312-1315. doi:10.1001/archsurg.1984.01390230078019.

31. Takada K, Nakamura K, Usuki N, et al. Rinsho Hoshasen 1989; 34(12): 1529-1532.

32. Sakamoto Y, Kubota K, Mori M, et al. Hepatogastroenterology 1999; 46(26): 1036-1041.

33. Morimoto T, Honda G, Oh Y, et al. J Gastroenterol 1999 34(1): 132-137. doi: 10.1007/s005350050229.
34. Shimahara Y, Shibata T, Morimoto T, et al. Surg Today 1999; 29(12): 1273-1276.

35. Momoi H, Shimahara Y, Terajima H, et al. Surg Today 2002; 32(12): 1035-1041. doi: 10.1007/s005950200210.

36. Paparel P, Tatou E, Krause D, et al. Prog Urol 2004; 14(2): 203-204.

37. Ben Abid S, Gharbi L, Arfa MN, et al. J Chir (Paris) 2005; 142(5): 311-312.

38. Fernández Sarabia MT, Rodríguez García JM, Cardenal Escarcena A, et al. Clin Transl Oncol 2008; 10(11): 761-763. doi: 10.1007/s12094-008-0284-8.

39. Wakayama K, Kamiyama T, Yokoo H, et al. World $J$ Surg Oncol 2013; 5(11): 259. doi: 10.1186/1477-7819-11-259.

40. Hiroyuki Tokue, Azusa Tokue, Yoshito Tsushima. $J$ Ovarian Res 2014; 7: 5. doi: 10.1186/1757-2215-7-5.

41. Yang ST, Liao YH, Lin WC, et al. J Obstet Gynaecol 2014; 34(2): 206-207. doi: 10.3109/01443615.2013.841657.

42. Filippi L, Sardella B, Ciorra A, et al. Cancer Biother Radiopharm 2014; 29(5): 189-192. doi: 10.1089/cbr.2014. 1612 .

43. Vishnevskiĭ AV, Andreĭtseva OI, Kharazov AF, et al. Khirurgiia (Mosk) 2015; 1: 68-72.

44. von Knobloch R, Schrader AJ, Walthers EM, Hofmann R. Urology 2009; 73(2): 333-336. doi: 10.1016/j.urology. 2008.09.037.

45. Rosenthal FD, Davies MK, Burden AC. Br Med J 1978; 1: 1591-1592. doi: 10.1136/bmj.1.6127.1591-a

46. Schomer NS, Mohler JL. J Urol 1995; 153: 1196-1198. 


\section{ADRENAL METASTASES OF RENAL CELL CARCINOMA WITH INTRAVENOUS TUMOR THROMBI OF THE INFERIOR VENA CAVA (two case reports with literature review)}

D. V. Shchukin ${ }^{1,2}$, V. N. Lesovoy ${ }^{1,2}$, U. M. Balarabe ${ }^{1}$, G. G. Khareba ${ }^{1,2}$, I. M. Antonian ${ }^{3}$, M. P. Kopytsya ${ }^{4}$, A. I. Harahatyi ${ }^{1,2}$, A. V. Shus ${ }^{3}$

${ }^{1}$ Kharkiv National Medical University, Kharkiv, Ukraine;

${ }^{2}$ MHI «V. I. Shapoval Regional Medical Clinical Center of Urology and Nephrology», Kharkiv, Ukraine;

${ }^{3}$ Kharkiv medical academy of postgraduate education, Kharkiv, Ukraine;

${ }^{4}$ L. T. Malaya National Institute of Therapy of NAMS of Ukraine, Kharkiv, Ukraine urology.edu.ua@gmail.com

Intrvenous extension is one of the features of neoplastic process and is very characteristic for tumors of the kidneys and adrenal glands. However, reports about the penetration of adrenal metastases into the venous system are extremely rare. We have presented two case reports on intravenous extension of renal cell carcinoma adrenal metastases. One of them for the first time in worldwide literature presents intravenous extension of synchronous bilateral adrenal metastases RCC into inferior vena cava and left renal vein. The patient underwent bilateral adrenalectomy with the use of hormone replacement therapy and targeted therapy with pazopanib. MDCT after 2 and 6 months did not show tumor progression. Lungs metastases are reduced in size or remained unchanged. The patient does not complain. Blood pressure 110/70 mm Hg. Symptoms of Addison's disease are absent.

In the second case, there was a metachronic contralateral metastasis of RCC, which penetrated through the right adrenal vein into the subhepatic section of the inferior vena cava. The patient underwent a right-sided adrenalectomy with thrombectomy. After 6 months multiple pulmonary metastases were identified. Pazopanib therapy has initiated. Three months later, tumor progression was revealed. The patient died after 5 months (14 months after surgery) from tumor intoxication.

Although these cases are extremely rare ( 7 cases in the world literature), it is necessary to take into account possibility of presence of venous tumor thrombi with adrenal metastases. The incidence of this phenomenon of $\mathrm{RCC}$ is in the second place after hepatocellular carcinoma (15 cases). Organ-sparing surgical technique in these patients is not feasible. Targeted therapy along with hormone replacement therapy was not accompanied by increased side effects or exacerbation of adrenal insufficiency after removal of both adrenal glands.

Key words: renal cell carcinoma, adrenal metastases, intravenous invasion, tumor thrombus.

\section{АДРЕНАЛЬНЫЕ МЕТАСТАЗЫ ПОЧЕЧНО-КЛЕТОЧНОГО РАКА С ВНУТРИВЕНОЗНЫМИ ОПУХОЛЕВЫМИ ТРОМБАМИ НИЖНЕЙ ПОЛОЙ ВЕНЫ (два клинических случая и обзор литературы)}

Щукин Д. В. ${ }^{1,2}$, Лесовой В. Н. ${ }^{1,2}$, Баларабе У. М. ${ }^{1}$, Хареба Г. Г. ${ }^{1,2}$, Антонян И. М. ${ }^{3}$, Копица Н. П. ${ }^{4}$, Гарагатый А. И., ${ }^{1,2}$, Шусь А. В. ${ }^{3}$

${ }^{1}$ Харьковский национальный медицинский университет, г. Харьков, Украина;

${ }^{2}$ КНП ХОР «Областной медицинский клинический центр урологии и нефрологии ил. В. И. Шаповала», г. Харьков, Украина;

${ }^{3}$ Харьковская медииинская академия последипломного образования, г. Харьков, Украина;

${ }^{4}$ Национальный институт терапии им. Л. Т. Малой НАМН Украины, г. Харьков, Украина urology.edu.ua@gmail.com

Внутривенозное распространение является одной из особенностей неопластического процесса и очень характерно для опухолей почек и надпочечников. Однако сообщения о прорастании в венозную систему адренальных метастазов крайне редки. Мы представили два клинических наблюдения внутривенозного распространения адренальных метастазов почечно-клеточного рака. Одно из них впервые в мировой литературе описывает синхронное внутривенозное распространение билатеральных адренальных метастазов ПКР в нижнюю полую вену справа и в основную левую почечную вену слева. Пациенту была проведена билатеральная адреналэктомия с последующей заместительной гормональной и таргетной терапией пазопанибом. МДКТ через 2 и 6 месяцев не продемонстрировала прогрессии опухоли. Большинство объемных образований легких уменьшилось в размерах или оставалось без изменений. Пациент не предъявляет жалоб. Артериальное давление 110/70 мм рт. ст. Симптомы болезни Аддисона отсутствуют.

Во втором случае имел место метахронный контралатеральный метастаз ПКР, который через правую адренальную вену проникал в подпеченочный отдел нижней полой вены. Пациентке была выполнена правосторонняя адреналэктомия с тромбэктомией. Через 6 месяцев у нее обнаружены множественные легочные метастазы. Начата терапия пазопанибом. Три месяца спустя была идентифицирована прогрессия опухоли. Пациентка умерла через 5 месяцев (через 14 месяцев после операции) от опухолевой интоксикации. 
Хотя данные наблюдения являются экстремально редкими (7 случаев в мировой литературе), необходимо учитывать возможность существования опухолевых венозных тромбов при метастазах почечно-клеточного рака в надпочечники. По частоте встречаемости данного феномена ПКР занимает второе место после гепатоцеллюлярного рака (15 случаев). Органосохраняющая хирургическая тактика у данных пациентов не является возможной. Таргетная терапия на фоне заместительной гормональной терапии не сопровождалась увеличением числа побочных эфффектов или усилением адренальной недостаточности у пациента после удаления обоих надпочечников.

К лючевые слов а: почечно-клеточный рак, адренальные метастазы, инравенозное распространение, опухолевый тромб.

\section{АДРЕНАЛЬНІ МЕТАСТАЗИ НИРКОВО-КЛІТИННОГО РАКА З ВНУТРІШНЬОВЕНОЗНИМИ ПУХЛИННИМИ ТРОМБАМИ НИЖНЬОÏ ПОРОЖНИСТОÏ ВЕНИ (два клінічних випадки та огляд літератури)}

Щукін Д. В. ${ }^{1,2}$, Лісовий В. М. ${ }^{1,2}$, Баларабе У. М. ${ }^{1}$, Хареба Г. Г. ${ }^{1,2}$,

Антонян I. М. ${ }^{3}$, Копиця М. П. ${ }^{4}$, Гарагатий А. I. ${ }^{1,2}$, Шусь А. В. ${ }^{3}$

${ }^{1}$ Харківський наиіональний медичний уіиверситет, л. Харків, Украйна;

${ }^{2}$ КНП ХОР "Обласний медичний клінічний иентр урологї і нефбрологї іл. В. I. Шаповала», м. Харків, Украӥна;

${ }^{3}$ Харківська медична академія післядипломної освіти, м. Харків, Украӥна;

${ }^{4}$ Національний інститут терапї іл. Л. Т. Малої НАМН Украӥны, м. Харків, Україна

urology.edu.ua@gmail.com

Внутрішньовенозне поширення е однією з особливостей неопластического процесу і дуже характерно для пухлин нирок і надниркових залоз. Однак повідомлення про проростання у венозну систему адренальних метастазів е дуже рідкісними. Ми представили два клінічних спостереження внутрішньовенозного поширення адренальних метастазів нирково-клітинного раку. Одне з них вперше в світовій літературі описуе синхронну внутрішньовенозну інвазію білатеральних адренальних метастазів нирково-клітинного раку в нижню порожнисту вену праворуч і в основну ліву ниркову вену ліворуч. Пацієнту була виконана білатеральна адреналектомія з подальшою замісною гормональною і таргетною терапією пазопанібом. МДКТ через 2 і 6 місяців не продемонструвала прогресії пухлини. Більшість об'ємних утворень легенів зменшилася в розмірах або залишалося без змін. Пацієнт не пред'являє скарг. Артеріальний тиск 110/70 мм рт. ст. Симптоми хвороби Аддісона відсутні.

У другому випадку мав місце метахронний контралатеральний метастаз НКР, який через праву адренальнуо вену проникав до підпечінкового відділу нижньої порожнистої вени. Пацієнтці була виконана правобічна адреналектомія з тромбектомією. Через 6 місяців у неї виявлені множинні легеневі метастази. Розпочато терапія пазопанібом. Три місяці по тому була ідентифікована прогресія пухлини. Пацієнтка померла через 5 місяців (через 14 місяців після операції) від пухлинної інтоксикації.

Хоча ці клінічні випадки е екстремально рідкісними (7 випадків), необхідно враховувати можливість існування пухлинних венозних тромбів при метастазах нирково-клітинного раку в наднирники. За частотою зустрічаємості даного френомена нирково-клітинний рак посідає друге місце після гепатоцелюлярного раку (15 випадків). Органозберігаюча хірургічна тактика у даних пацієнтів не можлива. Таргетная терапія на тлі замісної гормональної терапії не супроводжувалася збільшенням кількості побічних ефектів або посиленням адренальної недостатності у паціента після видалення обох наднирників.

К лючові слова: нирково-клітинний рак, адренальні метастази, інравенозне поширення, пухлинний тромб. 